\title{
HPLC Method for Simultaneous Determination of Ascorbic acid, Phenylephrine, Paracetamol, Caffeine in Their Pure and Dosage Forms
}

\author{
Yara Elkady, Sobhy M. El-Adl, Mohamed Baraka, Mahmoud M. Sebaiy" \\ Department of Medicinal Chemistry, Faculty of Pharmacy, Zagazig University, Zagazig, Egypt \\ *Corresponding Author: Mahmoud M. Sebaiy, Department of Medicinal Chemistry, Faculty of Pharmacy, \\ Zagazig University, Zagazig, Egypt
}

\begin{abstract}
An isocratic HPLC method has been developed for determination of ascorbic acid, phenylephrine, paracetamol, and caffeine in their pure and tablet forms. Separation was carried out at room temperature on an Kinetex $2.6 \square$ C18 100A (4.6 $\mathrm{mm} \times 100 \mathrm{~mm})$ column using a mobile phase of $0.05 \mathrm{M}$ potassium dihydrogen phosphate buffer (pH 3.50 by ortho-phosphoric acid): acetonitrile: methanol (70:20:10). The flow rate was 1 $\mathrm{mL} / \mathrm{min}$, maximum absorption was measured at $220 \mathrm{~nm}$ and linearity was in the range of $1-50 \mu \mathrm{g} / \mathrm{mL}$ for all drugs. The retention times of ascorbic acid, phenylephrine, paracetamol and caffeine were reported to be 1.83 , 2.94, 3.74 and 5.13 minutes, respectively, indicating a very short analysis time compared with other reported methods. Also, limits of detection were reported to be 0.76, 0.82, 0.47 and $0.24 \mu \mathrm{g} / \mathrm{mL}$ for ascorbic acid, phenylephrine, paracetamol, and caffeine respectively, showing a high degree of the method sensitivity. The proposed method was validated in terms of linearity, accuracy, precision and robustness according to ICH guidelines and results were compared statistically with reference methods in respect of precision and accuracy.
\end{abstract}

Keywords: HPLC; ascorbic acid; phenylephrine; paracetamol; caffeine; ICH guidelines

\section{INTRODUCTION}

Ascorbic acid (ASC), is chemically (2R)-2-[(1S)-1,2-dihydroxyethyl]-3,4-dihydroxy-2H-furan-5-one ( Figure 1). It is a water-soluble vitamin (Vitamin C) and synthesized by eukaryotes only. It was isolate d from the adrenal cortex by Albert Szent-Györgyi in 1928 [1]. It is found naturally in certain foods, a dded to others, and available as a dietary supplement. Unlike most animals, humans cannot endogenou sly synthesize ASC, so it is an important dietary compound [2]. ASC is an essential component of plan $\mathrm{t}$ and animal antioxidant systems which can be characterized as complex redox networks with mutual $i$ nteractions and synergistic effects, including metabolites and enzymes [3]. ASC is necessary for the bi ogenesis of collagen, L-carnitine, cholesterol as well as some neurotransmitters [4]. It also has the pote ntial involvement in cancer and cardiovascular diseases [5-7]. The effects of vitamin $C$ in the treatmen $\mathrm{t}$ of ocular disease was investigated, illustrating that ascorbate influences cataract development [8]. Hi gh-performance liquid chromatography (HPLC) [9-13], thin layer chromatography (TLC) [14-17] and spectrophotometric methods [18-20] were developed for the quantification of ASC in pharmaceutical a nd biological samples.

Phenylepherine (PHE), is chemically (1R,2S)- respectively (1S,2R)-2-methylamino-1-phenylpropan-1 -ol (Figure 1). PHE is $\alpha 1$-adrenergic receptor agonist; it is a potent, synthetic, sympathomimetic eleme nt that has been reported to have significant vasoconstrictor confidants when intravenously dosed. PH $\mathrm{E}$ appears to have no effect on the heart's beta receptor cells. When given intravenously, it blunts the $\mathrm{h}$ eart rate but increases the stroke output thereby causing diastolic and systolic pressures to rise [21]. PH $\mathrm{E}$ is a drug used for nasal congestion, hypertension, sinusitis and rhinitis [22]. PHE is now the preferre $\mathrm{d}$ vasopressor during the elective caesarean section but it can trigger bradycardia reflex [23]. PHE was determined by several methods such as HPLC [24-26], TLC [27-30], spectrophotometric [31-33] and s pectrofluorimetric methods [34].

Paracetamol (PAR), is chemically N-(4-hydroxyphenyl)acetamide, (Figure 1). As an analgesic and ant ipyretic agent, PAR or acetaminophen is commonly used [35]. It is a safe and effective analgesic agen $t$ used to treat viral and bacterial infections as well as to alleviate pain associated with migraine, backa che, cephalagra and post-operative pain fevers [36]. HPLC methods were developed for the quantificat 
ion of PAR [37-40]. Also, TLC methods were used in several experiments for the evaluation of PAR [ 41,42]. In addition, highly sensitive UV spectrophotometric methods were used for the characterizatio $\mathrm{n}$ of PAR in different samples $[38,43,44]$.

Caffeine (CAF), is chemically 1,3,7-trimethyl-1H-purine-2,6 (3H,7H)-dione (Figure 1). It is a natural a lkaloid commonly used in the food industry as the most beneficial psychostimulant for motor stimulati on, mood improvement, information processing and cognitive / motor output in beverages or foods. C AF can have both positive and negative effects on the health [45]. It is on the one hand, powerful stim ulant on the central nervous system and also induces the cardiac muscle. On the other hand, its high le vels have visible gastrointestinal tract irritation and may induce anxiety, insomnia, irritability and head aches resulting from the "caffeinism" syndrome [45]. Several analytical methods such as HPLC [46-49 ] and MS-detection [50], capillary electrophoresis (CE) with UV-detection [51], gas chromatograph w ith flame ionization detection (GC-FID) [52], TLC [53-55], voltammetry [56], synchronous fluorescen ce [57] and spectrophotometric method $[58,59]$ had been developed for the determination of CAF in $\mathrm{s}$ everal matrices.<smiles>O=C1O[C@H]([C@@H](O)CO)C(O)=C1O</smiles>

ASC<smiles>CC(=O)Nc1ccc(O)cc1</smiles>

PAR<smiles>CNCC(O)c1cccc(O)c1</smiles>

PHE<smiles>Cn1c(=O)c2c(ncn2C)n(C)c1=O</smiles>

CAF

Figure1. Chemical structures of ascorbic acid (ASC), phenylephrine (PHE), paracetamol (PAR), caffeine (CAF)

To the best of our knowledge, there is a reported method [13] for the simultaneous chromatographic se paration of ASC, PHE, PAR, and CAF but it some limitations were reported in respect of high linearit y range and LODs. As such, the present work introduces a simple, rapid, reproducible and very sensiti ve chromatographic method with lower LOD values that has been established and validated for the det ermination of ASC, PHE, PAR, and CAF in their pure forms and in their tablet dosage form according to ICH guidelines [60].

\section{MATERIALS AND METHODS}

\subsection{Instrumentation}

High performance liquid chromatography (HPLC) apparatus is equipped with Surveyor quaternary pu $\mathrm{mp}$ with Intel vacuum degasser (Agelint 1100), a Surveyor autosampler plus (Thermo Scientific Co., U SA), Kinetex $2.6 \mu \mathrm{C}_{18}$ 100A (4.6 mm $\left.\times 100 \mathrm{~mm}\right)$ column (Thermo Scientific Co. USA), Autosampler vials $1.8 \mathrm{~mL}$ screw cap (Thermo Scientific, USA), and Surveyor photodiode array detector (PDA) (Th ermo Scientific Co. USA). A computer with a software chromo quest 5 (Surveyor Thermo Scientific C o. USA), has been used for data collection and analysis,.Consort $\mathrm{P} 400 \AA$ digital $\mathrm{pH}$-meter was used for $\mathrm{pH}$ adjustment.

\subsection{Chemicals and Reagents}

All solvents and reagents were of HPLC analytical grade. Acetonitrile and methanol HPLC grade were supplied by Fischer scientific (Loughborough, UK), while ortho-phosphoric acid was purchased from Merck (Darmstadt, Germany) and water used in all the experiments was obtained from Milli-RO and Milli-Q systems (Millipore, Bedford, MA). Standard powders of ASC,PHE, PAR and CAF were kindl y supplied by EIPICO (Egypt) . 
HPLC Method for Simultaneous Determination of Ascorbic acid, Phenylephrine, Paracetamol, Caffeine in Their Pure and Dosage Forms

\subsection{Chromatographic Conditions}

HPLC was connected with Kinetex $2.6 \mu \mathrm{C}_{18} 100 \mathrm{~A}(4.6 \mathrm{~mm} \times 100 \mathrm{~mm})$ column as a stationery phase. A mixture of $0.05 \mathrm{M}$ potassium dihydrogen phosphate buffer ( $\mathrm{pH} 3.50$ by ortho-phosphoric acid), acet onitrile, methanol a ratio of 70:20:10 (v/v/v) was freshly prepared and used as an isocratic mobile phas e. The mobile phase was pumped at a flow rate of $1 \mathrm{~mL} / \mathrm{min}$. The injection volume was $10 \mu \mathrm{L}$ and the column was maintained at ambient temperature while the eluent was monitored at $220 \mathrm{~nm}$. All chroma tographic conditions are illustrated in Table 1.

Table1. Chromatographic Conditions for the proposed method

\begin{tabular}{|c|c|}
\hline Parameters & Conditions \\
\hline Column & Kinetex $2.6 \mu \mathrm{C}_{18} 100 \mathrm{~A}(4.6 \mathrm{~mm} \times 100 \mathrm{~mm})$ \\
\hline Mobile phase & $\begin{array}{c}\text { M potassium dihydrogen phosphate buffer }(\mathrm{pH} 3.50 \mathrm{using} \text { ortho- } \\
\text { phosphoric acid): acetonitrile: methanol }(70: 20: 10, \mathrm{v} / \mathrm{v} / \mathrm{v})\end{array}$ \\
\hline UV detection, $\mathbf{n m}$ & 220 \\
\hline Flow rate, $\mathbf{m L} / \mathbf{m i n}$ & 1 \\
\hline Injected volume, $\boldsymbol{\mu L}$ & 10 \\
\hline Temperature & Ambient \\
\hline
\end{tabular}

\subsection{Preparation of Standard Stock Solution and Construction of Calibration Curves}

Standard stock solution of ASC, PHE, PAR and CAF $(100 \mu \mathrm{g} / \mathrm{mL})$ was prepared by dissolving $10 \mathrm{mg}$ of each pure drug in $100 \mathrm{~mL}$ water. Then, Standard solution was diluted by methanol to get final conc entrations of $1,5,10,15,20$ and $50 \mu \mathrm{g} / \mathrm{mL}$ for all drugs for construction of calibration plots. The mixt ure was injected in triplicate and chromatographed under the previously mentioned conditions. A linea $\mathrm{r}$ relationship was obtained when average drug standard peak areas were plotted against the correspond ing concentrations for each drug and regression equations were computed.

\subsection{Pharmaceutical Preparations}

10 tablets (6 mg ASC, $0.5 \mathrm{mg}$ PHE, $40 \mathrm{mg}$ PAR and 3.5 CAF) were weighed and finely powdered. An accurately weighed portion from the powdered tablets equivalent to the average concentration of one $t$ ablet was transferred into a $100 \mathrm{~mL}$ volumetric flask. $80 \mathrm{~mL}$ of water were added and sonicated for 20 minutes then the volume was completed with diluent to $100 \mathrm{~mL}$ and filtered. Further dilution was perf ormed to obtain the required concentration range of the drug mixture.

\section{RESULTS AND DISCUSSION}

\subsection{Optimization of Chromatographic Conditions}

Several trials were done to obtain the optimized chromatographic condition for determination of ASC, PHE, PAR, and CAF. First, chromatographic detection was performed at 220, 215, and $210 \mathrm{~nm}$ using a PDA detector and the optimal wavelength was set at $220 \mathrm{~nm}$. Second trials were carried out by changi ng mobile phase composition to reach the optimum separation with good resolution where the mobile phase $0.05 \mathrm{M}$ potassium dihydrogen phosphate buffer ( $\mathrm{pH} 3.50$ by ortho-phosphoric acid), acetonitrile , methanol at a ratio of 70:20:10, v/v/v was chosen as the optimum one based on faster separation and good peak resolution. Final trials were carried out to show the effect of different flow rates and optima 1 separation was achieved at a flow rate of $1 \mathrm{~mL} / \mathrm{min}$. Under these conditions, ASC, PHE, PAR, and C $\mathrm{AF}$ in pure form were separated and eluted at 1.83, 2.94, 3.74 and 5.13 minutes, respectively as illustra ted in Figure 2(A) and in dosage form as illustrated in Figure 2(B). However, the optimum mobile pha se showed symmetrical peaks $(0.86<\mathrm{T}<1.22)$, capacity factor $(1<\mathrm{k}<10)$, resolution $>2$ and theore tical plates $>2000$ which are in agreement with the CDER values recommendation [61]. Table 2 show $\mathrm{s}$ all system suitability parameters of the proposed HPLC method for simultaneous determination of th e four drugs in pure form. 
HPLC Method for Simultaneous Determination of Ascorbic acid, Phenylephrine, Paracetamol, Caffeine in Their Pure and Dosage Forms

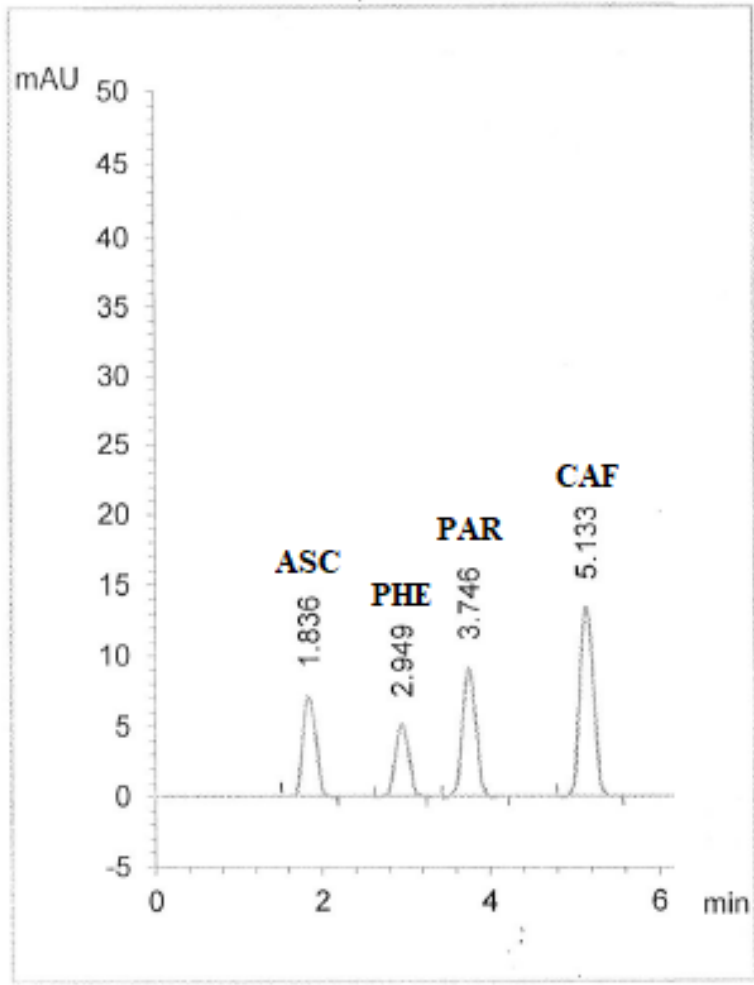

A

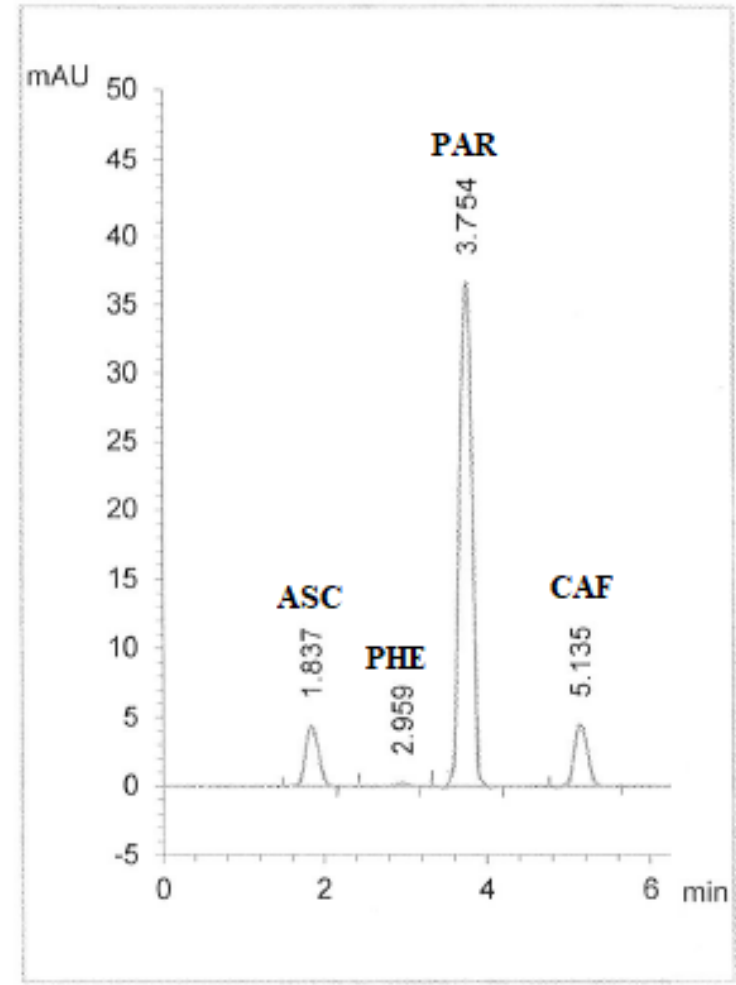

B

Figure2. Typical HPLC chromatograms obtained from ASC, PHE, PAR and CAF using Kinetex $2.6 \mu C_{18} 100 A$ $(4.6 \mathrm{~mm} \times 100 \mathrm{~mm})$ column in (A) pure form and (B) pharmaceutical formulation using mobile phase of $0.05 \mathrm{M}$ potassium dihydrogen phosphate buffer (pH 3.50 by ortho-phosphoric acid): acetonitrile: methanol (70:20:10, $v / v / v)$. Other chromatographic conditions are stated in Table 1

Table2. System suitability parameters for ascorbic acid (ASC), phenylephrine (PHE), paracetamol (PAR) and caffeine $(C A F)$ in their pure form

\begin{tabular}{|c|c|c|c|c|c|}
\hline Parameters & ASC & PHE & PAR & CAF & Reference values [61] \\
\hline Retention time, tr & 1.86 & 2.92 & 3.37 & 5.16 & \\
\hline Capacity factor, $\mathbf{k}^{\prime}$ & 2.21 & 2.41 & 2.11 & 2.31 & Accepted k' value (1-10) \\
\hline Peak asymmetry (Tailing factor, $\mathbf{T})$ & 1.08 & 1.22 & 0.91 & 0.86 & Accepted T value $\leq 2$ \\
\hline Therotical plates, $\mathbf{N}$ & 5886 & 6769 & 6233 & 7561 & Accepted N value > 2000 \\
\hline Resolution, Rs & 8.32 & 7.68 & 6.63 & 9.52 & Accepted value > 2 \\
\hline Selectivity (Separation factor, $\boldsymbol{\alpha})$ & 8.25 & 8.02 & 8.22 & 8.16 & \\
\hline
\end{tabular}

\subsection{Method Validation}

The proposed method was validated according to ICH guidelines [61] in terms of specificity, linearity, precision, accuracy, robustness, limit of detection and limit of quantification.

\subsubsection{Specificity}

specificity, is the ability of an analytical method to distinguish the analyte from other chemicals in the sample. The specificity of the method was assessed by deliberately adding impurities into a sample co ntaining the analyte and testing how well the method can identify the analyte. It was found that there $\mathrm{w}$ as no interference due to excipients found in tablet formulation as seen in Figure 2(B).

\subsubsection{Linearity}

Six different concentrations of the drug mixture were specified for linearity studies in the range of 1-5 $0 \mu \mathrm{g} / \mathrm{mL}$ for all drugs as seen in Table 3. A linear relationship was established by plotting concentratio ns against corresponding peak areas. The correlation coefficient was around 0.999 indicating good line arity as shown in Figure 3. Also, the regression equations were found to be $y=5.086 x+1.093, y=4.91$ $1 \mathrm{x}+1.301, \mathrm{y}=7.124 \mathrm{x}+1.074$, and $\mathrm{y}=8.15 \mathrm{x}-1.015$, for ASC, PHE, PAR, and CAF respectively. 
HPLC Method for Simultaneous Determination of Ascorbic acid, Phenylephrine, Paracetamol, Caffeine in Their Pure and Dosage Forms

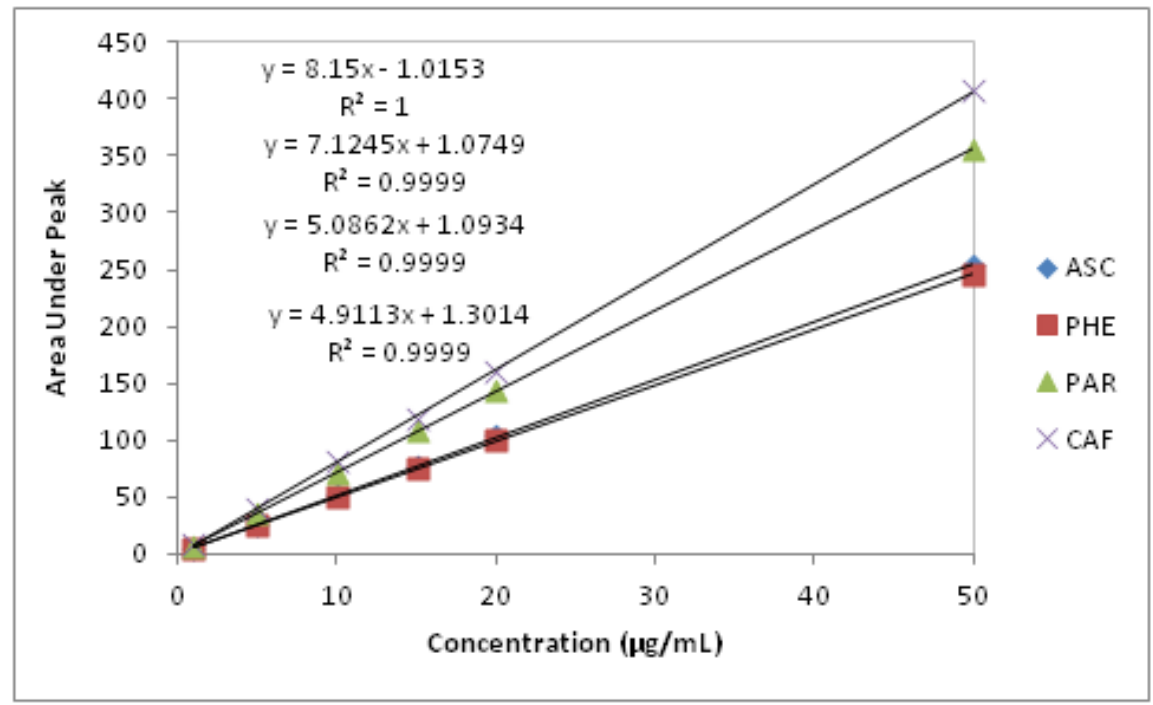

Figure3. Calibration curves of ASC, PHE, PAR, and CAF using the proposed HPLC method

Table3. Results of analysis for the four drugs in pure form using the proposed method

\begin{tabular}{|c|c|c|c|c|c|c|c|c|c|c|c|}
\hline \multicolumn{3}{|c|}{ ASC } & \multicolumn{3}{|c|}{ PHE } & \multicolumn{3}{|c|}{ PAR } & \multicolumn{3}{|c|}{ CAF } \\
\hline $\begin{array}{c}\text { Take } \\
\mathbf{n} \\
\mu \mathrm{g} / \mathrm{m} \\
\mathrm{L} \\
\end{array}$ & $\begin{array}{c}\text { Foun } \\
\mathrm{d} \\
\mu \mathrm{g} / \mathrm{m} \\
\mathrm{L}\end{array}$ & $\begin{array}{c}\text { Recove } \\
\text { ry \% }\end{array}$ & $\begin{array}{c}\text { Take } \\
n \\
\mu \mathrm{g} / \mathrm{m} \\
\mathrm{L} \\
\end{array}$ & $\begin{array}{c}\text { Foun } \\
\mathrm{d} \\
\mu \mathrm{g} / \mathrm{m} \\
\mathrm{L} \\
\end{array}$ & $\begin{array}{c}\text { Recove } \\
\text { ry \% }\end{array}$ & $\begin{array}{c}\text { Take } \\
\mathbf{n} \\
\mu \mathrm{g} / \mathrm{m} \\
\mathrm{L} \\
\end{array}$ & $\begin{array}{c}\text { Foun } \\
\text { d } \\
\mu \mathrm{g} / \mathrm{m} \\
\mathrm{L} \\
\end{array}$ & $\begin{array}{l}\text { Recove } \\
\text { ry \% }\end{array}$ & $\begin{array}{c}\text { Take } \\
\text { n } \\
\mu \mathrm{g} / \mathrm{m} \\
\mathrm{L} \\
\end{array}$ & $\begin{array}{c}\text { Foun } \\
\mathrm{d} \\
\mu \mathrm{g} / \mathrm{m} \\
\mathrm{L} \\
\end{array}$ & $\begin{array}{c}\text { Recove } \\
\text { ry \% }\end{array}$ \\
\hline 1 & 0.97 & 97.34 & 1 & 1.01 & 101.12 & 1 & 0.98 & 97.93 & 1 & 0.98 & 98.01 \\
\hline 5 & 4.98 & 99.61 & 5 & 4.89 & 97.86 & 5 & 4.98 & 99.61 & 5 & 4.91 & 98.13 \\
\hline 10 & 10.05 & 100.52 & 10 & 9.87 & 98.72 & 10 & 9.92 & 99.16 & 10 & 9.80 & 98.02 \\
\hline 15 & 15.06 & 100.37 & 15 & 15.13 & 100.87 & 15 & 15.11 & 100.77 & 15 & 14.71 & 98.07 \\
\hline 20 & 19.94 & 99.69 & 20 & 20.18 & 100.88 & 20 & 20.19 & 100.98 & 20 & 19.62 & 98.12 \\
\hline 50 & 49.02 & 98.04 & 50 & 49.93 & 99.85 & 50 & 49.91 & 99.81 & 50 & 49.83 & 99.67 \\
\hline \multirow{2}{*}{\multicolumn{2}{|c|}{ Mean }} & & & & & & & & & & \\
\hline & & 99.26 & & & 99.88 & & & 99.71 & & & 98.33 \\
\hline \multicolumn{2}{|c|}{$\pm \mathrm{SD}$} & 1.28 & & & 1.33 & & & 1.11 & & & 0.65 \\
\hline \multicolumn{2}{|c|}{ \pm RSD } & 1.29 & & & 1.34 & & & 1.12 & & & 0.66 \\
\hline \multicolumn{2}{|c|}{$\pm \mathrm{SE}$} & 0.57 & & & 0.60 & & & 0.50 & & & 0.29 \\
\hline \multicolumn{2}{|c|}{ Variance } & 1.66 & & & 1.79 & & & 1.25 & & & 0.42 \\
\hline \multicolumn{2}{|c|}{$\begin{array}{c}\text { LOD } \\
(\mu \mathrm{g} / \mathrm{mL})\end{array}$} & 0.76 & & & 0.82 & & & 0.47 & & & 0.24 \\
\hline \multicolumn{2}{|c|}{$\begin{array}{c}\text { LOQ } \\
(\mu \mathrm{g} / \mathrm{mL})\end{array}$} & 2.53 & & & 2.73 & & & 1.57 & & & 0.80 \\
\hline
\end{tabular}

\subsubsection{Limits of Detection and Quantification}

Limit of detection (LOD) of an analytical procedure is the lowest amount of analyte in a sample which can be detected but not necessarily quantitated as an exact value. Limit of quantification (LOQ) is the 1 owest amount of analyte in a sample which can be quantitatively determined with suitable precision an $\mathrm{d}$ accuracy. $\mathrm{LOD}=3.3 \mathrm{~S} / \mathrm{K}$ and $\mathrm{LOQ}=10 \mathrm{~S} / \mathrm{K}$, were used for the values calculation where $\mathrm{S}$ is the sta ndard deviation of three replicate determination values under the same conditions and $\mathrm{K}$ is the slope of calibration graph. LODs were reported to be $0.76,0.82,0.47$ and $0.24 \mu \mathrm{g} / \mathrm{mL}$, while LOQs were calcu lated to be $2.53,2.73,1.57$ and $0.80 \mu \mathrm{g} / \mathrm{mL}$ for ASC, PHE, PAR, and CAF respectively (Table 3 ). The se results show that the proposed method is highly sensitive in comparison with reported methods [13] and applicable not only for pharmaceutical analysis but also for pharmacokinetic studies. 
HPLC Method for Simultaneous Determination of Ascorbic acid, Phenylephrine, Paracetamol, Caffeine in Their Pure and Dosage Forms

\subsubsection{Precision}

The precision of the method was calculated in terms of repeatability and intermediate precision (intraday and inter-day precision). Standard deviation (SD) of five replicate determinations using the same $\mathrm{s}$ olution containing pure drug during the same day and five consecutive days were calculated as shown in Table 4. The SD values (1.30 to 1.78$)$ for intra-day and those (0.10 to 3.35) of inter-day prescision were in the acceptable range and showed that the proposed method has an adequate precision in respec $t$ of the simultaneous determination of the 4 cited drugs in their pharmaceutical formulation.

Table4. Results of Intra-and inter-day precision of the four drugs

\begin{tabular}{|c|c|c|c|c|c|}
\hline \multirow[t]{2}{*}{ Drugs } & \multirow{2}{*}{$\begin{array}{c}\text { Conc. } \\
\mu \mathrm{g} / \mathrm{mL}\end{array}$} & \multicolumn{2}{|c|}{ Intra-day } & \multicolumn{2}{|c|}{ Inter-day } \\
\hline & & Mean \pm SD & RSD \% & Mean \pm SD & RSD \% \\
\hline \multirow[t]{3}{*}{ ASC } & 5 & $96.54 \pm 1.57$ & 1.63 & $96.10 \pm 1.26$ & 1.13 \\
\hline & 10 & $97.43 \pm 1.58$ & 1.62 & $95.90 \pm 2.10$ & 2.12 \\
\hline & 15 & $97.29 \pm 1.57$ & 1.62 & $96.00 \pm 1.88$ & 1.96 \\
\hline \multirow[t]{3}{*}{ PHE } & 5 & $96.19 \pm 1.78$ & 1.86 & $96.30 \pm 0.10$ & 0.94 \\
\hline & 10 & $97.09 \pm 1.73$ & 1.79 & $99.69 \pm 3.35$ & 3.37 \\
\hline & 15 & $99.23 \pm 1.75$ & 1.26 & $101.50 \pm 2.83$ & 2.79 \\
\hline \multirow[t]{3}{*}{ PAR } & 5 & $98.90 \pm 1.33$ & 1.34 & $96.90 \pm 2.10$ & 2.18 \\
\hline & 10 & $98.46 \pm 1.30$ & 1.32 & $97.10 \pm 0.61$ & 0.63 \\
\hline & 15 & $100.06 \pm 1.32$ & 1.32 & $99.34 \pm 0.94$ & 0.95 \\
\hline \multirow[t]{3}{*}{ CAF } & 5 & $99.58 \pm 1.33$ & 1.34 & $98.37 \pm 0.50$ & 0.54 \\
\hline & 10 & $97.15 \pm 1.67$ & 1.67 & $100.07 \pm 0.91$ & 0.91 \\
\hline & 15 & $100.63 \pm 1.32$ & 1.31 & $99.13 \pm 0.20$ & 0.21 \\
\hline
\end{tabular}

\subsubsection{Accuracy and recovery}

Accuracy was assessed using 9 determinations over 3 concentration levels of 5,10 , and $15 \mu \mathrm{g} / \mathrm{mL}$ cov ering the specified ranges. The results showed excellent recoveries with lower SD values as seen in table 5.

Table5. Results of accuracy study (recovery)

\begin{tabular}{|c|c|c|c|c|c|c|c|c|c|}
\hline \multicolumn{2}{|c|}{ Drugs } & \multicolumn{2}{c|}{ ASC } & \multicolumn{2}{c|}{ PHE } & \multicolumn{2}{c|}{ PAR } & \multicolumn{2}{c|}{ CAF } \\
\cline { 3 - 10 } & & $\begin{array}{c}\text { Mean } \pm \\
\text { SD }\end{array}$ & RSD\% & $\begin{array}{c}\text { Mean } \pm \\
\text { SD }\end{array}$ & RSD\% & $\begin{array}{c}\text { Mean } \pm \\
\text { SD }\end{array}$ & RSD\% & $\begin{array}{c}\text { Mean } \pm \\
\text { SD }\end{array}$ & RSD\% \\
\hline \multirow{4}{*}{$\begin{array}{c}\text { Conc. } \\
\boldsymbol{\mu g} / \mathbf{m L}\end{array}$} & $\mathbf{5}$ & $\begin{array}{c}96.69 \pm \\
2.57\end{array}$ & 2.66 & $\begin{array}{c}97.50 \pm \\
0.86\end{array}$ & 0.88 & $\begin{array}{c}99.47 \pm \\
0.63\end{array}$ & 0.64 & $\begin{array}{c}98.20 \pm \\
2.05\end{array}$ & 2.09 \\
\cline { 2 - 10 } & $\mathbf{1 0}$ & $\begin{array}{c}99.79 \pm \\
1.25\end{array}$ & 1.25 & $\begin{array}{c}97.93 \pm \\
1.69\end{array}$ & 1.73 & $\begin{array}{c}98.83 \pm \\
0.94\end{array}$ & 0.95 & $\begin{array}{c}99.80 \pm \\
2.07\end{array}$ & 2.08 \\
\cline { 2 - 10 } & $\mathbf{1 5}$ & $\begin{array}{c}96.79 \pm \\
3.13\end{array}$ & 3.22 & $\begin{array}{c}101.90 \pm \\
1.61\end{array}$ & 1.61 & $\begin{array}{c}100.79 \pm \\
0.39\end{array}$ & 0.39 & $\begin{array}{c}99.30 \pm \\
2.04\end{array}$ & 2.05 \\
\hline
\end{tabular}

\subsubsection{Robustness}

Robustness of an analytical procedure is a measure of its capacity to remain unaffected by small variat ions in method parameters. In the proposed method, a small variation in the flow rate and mobile phas e composition showed a negliegble effect on the on the results as revealed by small $\mathrm{SD}$ values $(\mathrm{SD} \leq 3$ .97) for all applied changes (Table 6).

Table6. Results of robustness

\begin{tabular}{|c|c|c|c|c|}
\hline \multirow{2}{*}{ Drugs } & ASC & PHE & PAR & CAF \\
\cline { 2 - 4 } & Mean \pm SD & Mean \pm SD & Mean \pm SD & Mean \pm SD \\
\hline pH 3 & $93.12 \pm 0.49$ & $96.17 \pm 2.63$ & $99.60 \pm 0.81$ & $99.00 \pm 0.78$ \\
\hline pH 4 & $93.19 \pm 0.58$ & $97.49 \pm 3.92$ & $100.11 \pm 2.29$ & $99.20 \pm 0.33$ \\
\hline Mobile phase (68:22:10) & $94.90 \pm 0.54$ & $99.75 \pm 2.62$ & $96.60 \pm 0.81$ & $100.58 \pm 0.78$ \\
\hline Mobile phase (72:18:10) & $95.10 \pm 0.59$ & $101.2 \pm 3.97$ & $97.14 \pm 2.25$ & $100.70 \pm 0.33$ \\
\hline
\end{tabular}

\subsubsection{Application on Pharmaceutical Preparation}

The proposed method was successfully applied on pharmaceutical preparation containing ASC, PHE, PAR, and CAF. Results obtained were established in Table 7, showing a high degree of accuracy and $p$ recision where excipients and impurities did not show interference on the selected values. Also, results 
HPLC Method for Simultaneous Determination of Ascorbic acid, Phenylephrine, Paracetamol, Caffeine in Their Pure and Dosage Forms

obtained were compared to those obtained by reference methods $[11,26,37,47]$ where Student's t-test a nd F-test were performed for comparison. Results shown in Table 8 indicated that calculated $\mathrm{t}$ and $\mathrm{F} \mathrm{v}$ alues were less than tabulated ones for the 4 drugs which in turn indicate that there is no significant dif ference between proposed method and reference ones relative to precision and accuracy.

Table7. Results of analysis of ASC, PHE, PAR and CAF in pharmaceutical formulations

\begin{tabular}{|c|c|c|c|c|c|c|c|c|c|c|c|}
\hline \multicolumn{3}{|c|}{ ASC } & \multicolumn{3}{|c|}{ PHE } & \multicolumn{3}{|c|}{ PAR } & \multicolumn{3}{|c|}{ CAF } \\
\hline $\begin{array}{c}\text { Take } \\
\text { n } \\
\mu \mathrm{g} / \mathrm{m} \\
\mathrm{L}\end{array}$ & $\begin{array}{c}\text { Foun } \\
\text { d } \\
\mu \mathrm{g} / \mathrm{m} \\
\mathrm{L}\end{array}$ & $\begin{array}{c}\text { Recove } \\
\text { ry \% }\end{array}$ & $\begin{array}{c}\text { Take } \\
\mathrm{n} \\
\mu \mathrm{g} / \mathrm{m} \\
\mathrm{L}\end{array}$ & $\begin{array}{c}\text { Foun } \\
\text { d } \\
\mu \mathrm{g} / \mathrm{m} \\
\mathrm{L}\end{array}$ & $\begin{array}{c}\text { Recove } \\
\text { ry \% }\end{array}$ & $\begin{array}{c}\text { Take } \\
\text { n } \\
\mu \mathrm{g} / \mathrm{m} \\
\mathrm{L}\end{array}$ & $\begin{array}{c}\text { Foun } \\
\text { d } \\
\mu \mathrm{g} / \mathrm{m} \\
\mathrm{L}\end{array}$ & $\begin{array}{c}\text { Recove } \\
\text { ry } \%\end{array}$ & $\begin{array}{c}\text { Take } \\
\text { n } \\
\mu \mathrm{g} / \mathrm{m} \\
\mathrm{L}\end{array}$ & $\begin{array}{c}\text { Foun } \\
\text { d } \\
\mu \mathrm{g} / \mathrm{m} \\
\mathrm{L}\end{array}$ & $\begin{array}{c}\text { Recove } \\
\text { ry \% }\end{array}$ \\
\hline 3 & 2.97 & 99.02 & 0.25 & 0.24 & 99.28 & 20 & 19.29 & 96.49 & 1.75 & 1.73 & 99.27 \\
\hline 6 & 5.99 & 99.99 & 0.50 & 0.48 & 96.70 & 40 & 39.40 & 98.51 & 3.5 & 3.47 & 99.32 \\
\hline 9 & 9.02 & 100.29 & 0.75 & 0.74 & 98.90 & 60 & 59.09 & 98.49 & 5.25 & 5.19 & 99.01 \\
\hline 12 & 12.09 & 100.81 & 1 & 0.98 & 98.09 & 80 & 78.31 & $\begin{array}{l}97.88 \\
\end{array}$ & 7 & 7.02 & 100.3 \\
\hline 18 & 17.96 & 99.81 & 1.5 & 1.47 & 98.52 & 120 & 119.6 & 99.67 & 10.5 & 10.46 & 99.70 \\
\hline & & 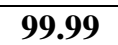 & & & 98.24 & & & 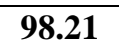 & & & 99.53 \\
\hline & & 0.66 & & & 1.14 & & & 1.15 & & & 0.52 \\
\hline & & 0.65 & & & 1.16 & & & 1.18 & & & 0.52 \\
\hline & & 0.29 & & & 0.51 & & & 0.51 & & & 0.23 \\
\hline Val & ince & 0.43 & & & 1.31 & & & 1.34 & & & 0.27 \\
\hline
\end{tabular}

Table8. Statistical analysis of results obtained by the proposed HPLC method applied on pharmaceutical formu lations compared with reference methods

\begin{tabular}{|c|c|c|c|c|c|c|c|}
\hline \multirow{2}{*}{ DRUG } & \multicolumn{4}{|c|}{ Recovery \pm SD } & $\begin{array}{c}\text { Reference } \\
\text { method } \\
\text { number }\end{array}$ & $\begin{array}{c}\text { Student } \\
\text { t- values }\end{array}$ & \multirow{2}{*}{ F- Values } \\
\cline { 2 - 8 } & $\begin{array}{c}\text { Proposed } \\
\text { Method }\end{array}$ & $\mathbf{N}$ & $\begin{array}{c}\text { Reference } \\
\text { Method }\end{array}$ & $\mathbf{N}$ & & \\
\hline ASC & $100.00 \pm 0.37$ & 4 & $100.30 \pm 0.17$ & 4 & {$[11]$} & $\mathbf{0 . 6 5}(1.94)^{\mathrm{a}}$ & $\mathbf{4 . 7 1}(6.39)^{\mathrm{b}}$ \\
\hline PHE & $100.60 \pm 0.29$ & 3 & $100.40 \pm 0.10$ & 3 & {$[26]$} & $\mathbf{0 . 6 4}(2.13)^{\mathrm{a}}$ & $\mathbf{7 . 9 3}(9.28)^{\mathrm{b}}$ \\
\hline PAR & $100.50 \pm 0.36$ & 3 & $100.00 \pm 0.13$ & 3 & {$[37]$} & $\mathbf{1 . 2 4}(2.13)^{\mathrm{a}}$ & $\mathbf{7 . 7 7}(9.28)^{\mathrm{b}}$ \\
\hline CAF & $99.43 \pm 0.13$ & 3 & $99.73 \pm 0.05$ & 3 & {$[47]$} & $\mathbf{2 . 0 7}(2.13)^{\mathrm{a}}$ & $\mathbf{6 . 4 8}(9.28)^{\mathrm{b}}$ \\
\hline
\end{tabular}

\section{CONCLUSION}

A simple, precise, accurate, valid, robust, highly sensitive and reliable HPLC method was established $\mathrm{f}$ or determination of ascorbic acid. phenylephrine, paracetamol and caffeine in bulk and pharmaceutica 1 preparation. In the proposed method, the chromatographic resolution was achieved within 6 minutes $\mathrm{f}$ or the four drugs. Linearity was observed over a concentration range of $1-50 \mu \mathrm{g} / \mathrm{mL}$ for all drugs. The method has been successfully applied for the analysis of tablet formulation in respect of quality control in addition to performing statistical comparison with reference methods showing no significant differences.

\section{REFERENCES}

[1] Szent-Gyorgyi, A Observations on the function of peroxidase systems and the chemistry of the adrenal cortex: Description of a new carbohydrate derivative. Biochem,1928, 1387-1409.

[2] Padayatty, S.J. and Levine, M. ,Vitamin C: The known and the unknown and Goldilocks. Oral Dis. 2016., 463-493.

[3] Paciolla, C., Paradiso, A. and de Pinto, M.C. Cellular redox homeostasis as central modulator in plant stress. In Redox State as a Central Regulator of Plant-Cell Stress Responses; Gupta, D.K., Palma, J.M., Corpas, F.J., Eds.; Springer: Cham, Switzerland,; pp.2016, 1-23. 
[4] Li, Y. and Schellhorn, H.E., New developments and novel therapeutic perspectives for vitamin C. J Nutr 2007,71-84.

[5] Pena E., Roa F. J., Inostroza E., Sotomayor K., Gonzalez M., Gutierrez-Castro F. A., et al. , Increased expression of mitochondrial sodium-coupled ascorbic acid transporter-2 (mitSVCT2) as a central feature in breast cancer. Free Radic. Biol. Med.2019, 283-292.

[6] Nyyssönen K., Parviainen M.T., Salonen R., Tuomilehto J. and Salonen J.T. . Vitamin C Deficiency and Risk of Myocardial Infarction: Prospective Population Study of Men from Eastern Finland. Br. Med. J.2016:634-638.

[7] Salvayre, R., Negre-Salvayre, A. and Camar, C., Oxidative theory of atherosclerosis and antioxidants. Biochimie. 2015:281-296.

[8] Lopes de Jesus, C.C., Atallah, A.N., Valente, O. and Moca Trevisani, V.F. ,. Vitamin C and superoxide dismutase (SOD) for diabetic retinopathy. Cochrane Database Syst Rev, 2008 ,CD006695.

[9] Kim, Y. and Ha, N. and Kim, M-G. Simultaneous determination of L-ascorbic acid and dehydroascorbic acid in human plasma. Analytical methods. 2015,7-10.

[10] Clark, Z. D. and Frank, E. L. . Development and implementation of an HPLC-ECD method for analysis of vitamin $\mathrm{C}$ in plasma using single column and automatic alternating dual column regeneration. Practical Laboratory Medicine, 2016, 25-37.

[11] Garnero, C. and Longhi, M. Development of HPLC and UV spectrophotometric methods for the determination of ascorbic acid using hydroxypropyl- $\beta$-cyclodextrin and triethanolamine as photostabilizing agents. Analytica chimica acta, ,2010, 159-166.

[12] Kand'ár, R., Drábková, P. and Hampl, R. . The determination of ascorbic acid and uric acid in human seminal plasma using an HPLC with UV detection. Journal of Chromatography B,2011, 2834-2839.

[13] Koblová, P., Sklenářová, H., Brabcová, I. and Solich, P. . Development and validation of a rapid HPLC method for the determination of ascorbic acid, phenylephrine, paracetamol and caffeine using a monolithic column. Analytical Methods, 2012, 1588-1591.

[14] Pyka-Pająk, A., Dołowy, M., Parys, W., Bober, K. and Janikowska, G. A Simple and Cost-Effective TLCDensitometric Method for the Quantitative Determination of Acetylsalicylic Acid and Ascorbic Acid in Combined Effervescent Tablets. Molecules,2018, 3115.

[15] Trineeva, O. V., Safonova, E. F. and Slivkin, A. I. Method Development for Quantitative Determination of Ascorbic Acid by High-Performance Thin-Layer Chromatography. Pharmaceutical Chemistry Journal, 2018, 938-944.

[16] Peter, E.L., Kaligirwa, A. and lukwago, T. Stability indicating high-performance thin-layer chromatography method for estimation of ascorbic acid in Hibiscus sabdariffa L. aqueous extract. Journal of complementary medicine research, 2019, 50-57.

[17] Alam, P., Kamal, Y.T., Alqasoumi, S.I., e t al. HPTLC method for simultaneous determination of ascorbic acid and gallic acid biomarker from freeze dry pomegranate juice and herbal formulation. Saudi Pharmaceutical Journal. 2019,:975-980.

[18] Shishehbore, M. R. and Aghamiri, Z. A highly sensitive kinetic spectrophotometric method for the determination of ascorbic Acid in pharmaceutical samples. Iranian journal of pharmaceutical research : IJPR, 2014, 373-382.

[19] Fadhel, D. H. . Spectrophotometric determination of ascorbic acid in aqueous solutions. Al-Nahrain Journal of Science, 2012, 88-94.

[20] Salkić, M. and Selimović, A., Spectrophotometric determination of L-ascorbic acid in pharmaceuticals based on its oxidation by potassium peroxymonosulfate and hydrogen peroxide. Croatica Chemica Acta, 2015, 73-79.

[21] Ok, S. H., Bae, S. I., Kwon, S. C., Park, J. C., Kim, W. C., Park, K. E., Shin, I. W., Lee, H. K., Chung, Y. K., Choi, M. J. and Sohn, J. T. Bupivacaine-induced Vasodilation Is Mediated by Decreased Calcium Sensitization in Isolated Endothelium-denuded Rat Aortas Precontracted with Phenylephrine. The Korean journal of pain, 2014,, 229-238.

[22] Desjardins, P. J. and Berlin, R. G.,. Efficacy of phenylephrine, Br. J. Clin. Pharmacol. 2007, 555-556.

[23] Kinsella, S.M., Carvalho, B., Dyer, R.A., et al., International consensus statement on the management of hypotension with vasopressors during caesarean section under spinal anaesthesia.Anaesthesia. 2018,71-92.

[24] Yadav, O. M., and H. K. Jain. ,RP-HPLC method development and validation for simultaneous estimation of phenylephrine hydrochloride and ebastine in tablet dosage form. International Journal of Pharmacy and Pharmaceutical Sciences, Sept. 2014. 466-70.

[25] Sanchaniya, P. M., Mehta, F. A. and Uchadadiya, N. B. . Development and validation of an RP-HPLC method for estimation of chlorpheniramine maleate, ibuprofen, and phenylephrine hydrochloride in 
combined pharmaceutical dosage form. Chromatography Research International, 2013.

[26] Pirol, O., Sukuroglu, M. and Ozden, T. . Simultaneous determination of Paracetamol, Phenylephrine hydrochloride, Oxolamine citrate and Chlorpheniramine maleate by HPLC in pharmaceutical dosage forms. E-Journal of Chemistry, 2011,8

[27] El Yazbi, F. A., Hassan, E. M., Khamis, E. F., Ragab, M. A. and Hamdy, M. M., Development and validation of a high-performance thin-layer chromatographic method for the simultaneous determination of two binary mixtures containing ketorolac tromethamine with phenylephrine hydrochloride and with febuxostat. Journal of chromatographic science, 2016, 819-828.

[28] Bhole, R. P., Jagadale, P. D., Chitlange, S. S. and Wankhede, S. B. A Simpl,e and Sensitive HPTLC Method for Simultaneous Analysis of Phenylephrine hydrochloride and Ketorolac tromethamine in Combined Dose Formulation. Analytical Chemistry Letters, 2015, 206-215.

[29] El-Kimary, E. I., Khamis, E. F., Belal, S. F. and Abdel Moneim, M. M. . Robust Chromatographic Methods for the Analysis of Two Quaternary Mixtures Containing Paracetamol, Codeine, Guaifenesin and Pseudoephedrine or Phenylephrine in their Dosage Forms. Journal of Chromatographic Science, 2019, 828837.

[30] Hegazy, M. A., Al-Ghobashy, M. A., Eltanany, B. M. nd Khattab, F. I.. 'Purity Indicating TLC Method for Quantitative Determination of Phenylephrine and Dimethindine Maleate in Presence of Dimethindine Maleate Impurity: 2-ethyl pyridine in Nasal Gel. J Pharmaceut Res, 2016, 1-6.

[31] Al-Sabha, T. ,Spectrophotometric Assay of Phenylephrine Hydrochloride Using 4-Aminoantipyrine and Copper (II). Pakistan Journal of Analytical and Environmental Chemistry. 2010. 01-07.

[32] Khoshayand, M. R., Abdollahi, H., Ghaffari, A., Shariatpanahi, M. and Farzanegan, H., Simultaneous spectrophotometric determination of paracetamol, phenylephrine and chlropheniramine in pharmaceuticals using chemometric approaches. Daru : journal of Faculty of Pharmacy, Tehran University of Medical Sciences, 2010, 292-297.

[33] Kazemipour, M. and Ansari, M. . Derivative spectrophotometry for simultaneous analysis of chlorpheniramine maleate, phenylephrine $\mathrm{HCl}$, and phenylpropanolamine $\mathrm{HCl}$ in ternary mixtures and pharmaceutical dosage forms.,2015.

[34] Saad R.A., Salim, M. M. and Hammad, S. F. , Synchronous spectrofluorometric methods for simultaneous determination of diphenhydramine and ibuprofen or phenylephrine in combined pharmaceutical preparations. Luminescence, 2020, 550-560.

[35] Kachoosangi, R. T., Wildgoose, G. G. and Compton, R. G.. Sensitive adsorptive stripping voltammetric determination of paracetamol at multiwalled carbon nanotube modified basal plane pyrolytic graphite electrode, Anal. Chim. Acta. 2008: 54-60.

[36] Shahrokhian, S. and Asadian, E. . Simultaneous voltammetric determination of ascorbic acid, acetaminophen and isoniazid using thionine immobilized multi-walled carbon nanotube modified carbon paste electrode, Electrochim. Acta.2010: 666-672.

[37] Abdelaleem, E. A., Naguib, I. A., Hassan, E. S. and Ali, N. W., HPTLC and RP-HPLC methods for simultaneous determination of paracetamol and pamabrom in presence of their potential impurities. Journal of pharmaceutical and biomedical analysis,2015, 22-27.

[38] Palur, K., Archakam, S. C. and Koganti, B. . Chemometric assisted UV spectrophotometric and RP-HPLC methods for simultaneous determination of paracetamol, diphenhydramine, caffeine and phenylephrine in tablet dosage form. Spectrochimica Acta Part A: Molecular and Biomolecular Spectroscopy, 2020,118801.

[39] Abdelwahab, N. S., Abdelrahman, M. M., Boshra, J. M. and Taha, A. A. . Different stability-indicating chromatographic methods for specific determination of paracetamol, dantrolene sodium, their toxic impurities and degradation products. Biomedical Chromatography, 2019, 45-98.

[40] Abdelaleem, E. A. and Abdelwahab, N. S. . Validated stability indicating RP-HPLC method for determination of paracetamol, methocarbamol and their related substances. Analytical Methods, 2013, 541545 .

[41] Mostafa, N. M. . Stability indicating method for the determination of paracetamol in its pharmaceutical preparations by TLC densitometric method. Journal of Saudi Chemical Society, 2010, 341-344.

[42] Abdelaleem, E. A. and Abdelwahab, N. S. . Stability-indicating TLC-densitometric method for simultaneous determination of paracetamol and chlorzoxazone and their toxic impurities. Journal of chromatographic science, 2013, 187-191.

[43] Ashour, A., Hegazy, M. A., Abdel-Kawy, M. and. ElZeiny, M. B., "Simultaneous spectrophotometric determination of overlapping spectra of paracetamol and caffeine in laboratory prepared mixtures and pharmaceutical preparations using continuous wavelet and derivative transform," Journal of Saudi Chemical Society, vol. 19, pp. 186-192, 2012. 
HPLC Method for Simultaneous Determination of Ascorbic acid, Phenylephrine, Paracetamol, Caffeine in Their Pure and Dosage Forms

[44] Vichare, V., Mujgond, P., Tambe, V. and Dhole, S. N. ,"Simultaneous spectrophotometric determination of paracetamol and caffeine in tablet formulation," International Journal of PharmTech Research, vol. 2, no. 4, pp. 2010,2512-2516.

[45] Reissig, C.J., Strain, E.C. and Griffiths, R.R.. Caffeinated energy drinks-A growing problem, Drug Alcohol Depend. 2009.: 1-10.

[46] Alvi, S. N. and Hammami, M. M. Validated HPLC method for determination of caffeine level in human plasma using synthetic plasma: application to bioavailability studies. Journal of chromatographic science, 2011, 292-296.

[47] Tsvetkova, B.G., Kostova, B.D., Rachev, D.R., Peikova, L.T. and Pencheva, I.P. HPLC assay and stability studies of tablets containing paracetamol and caffeine, International Journal of Pharmaceutical Sciences Review and Research. 2013, 138-142.

[48] Fernando, C. D. and Soysa, P. Simple isocratic method for simultaneous determination of caffeine and catechins in tea products by HPLC. SpringerPlus, 2016, 970.

[49] Dewani, A. P., Dabhade, S. M., Bakal, R. L., Gadewar, C. K., Chandewar, A. V. and Patra, S. ,Development and validation of a novel RP-HPLC method for simultaneous determination of paracetamol, phenylephrine hydrochloride, caffeine, cetirizine and nimesulide in tablet formulation. Arabian journal of chemistry, 2015, 591-598.

[50] Tzanavaras, P.D. and Themelis, D.G. ,Development and validation of a high-throughput high- performance liquid chromatographic assay for the determination of caffeine in food samples using a monolithic column, Analytica Chimica Acta. 2007: 89-94.

[51] Khasanov, V. V., Slizhov, Y.G. and Khasanov, V. V. ,Energy drink analysis by capillary electrophoresis, Journal of Analytical Chemistry. 2013, 357-359.

[52] Pasias, I., Kiriakou, I. Proestos, and C. , Development of a Rapid Method for the Determination of Caffeine in Coffee Grains by GC-FID_A Fully Validated Approach, Antioxidants.2017, 6.

[53] Sharma, P., Murthy, P. and Shivhare, P.., Validated high-performance thin layer chromatographic method for caffeine quantification in beverages and edibles. International Journal of Toxicology, 2014, 31-36.

[54] Oellig, C., Schunck, J. and Schwack, W. , Determination of caffeine, theobromine and theophylline in Mate beer and Mate soft drinks by high-performance thin-layer chromatography. Journal of Chromatography A, 2018, 208-212.

[55] Bhawani, S. A., Albishiri, H. M. and Rengarajan, R., Microemulsion thin-layer chromatographic separation of caffeine and paracetamol and their determination in formulated tablet and in spiked urine sample by HPLC. Analytical Chemistry Letters, 2014, 207-212.

[56] Tyszczuk-Rotko, K. and Bęczkowska, I. , Nafion covered lead film electrode for the voltammetric determination of caffeine in beverage samples and pharmaceutical formulations, Food Chemistry.2015, 24-29.

[57] Žiak, L., Májek, P., Hroboňová, K., Čacho, F. and Sádecká, J. , Simultaneous determination of caffeine, caramel and riboflavin in cola-type and energy drinks by synchronous fluorescence technique coupled with partial least squares, Food Chemistry. 2014, 282-286.

[58] Somya, K. V., Ravishankar, K., Basha, D. P. and Kiranmayi, G. V. N. , "Estimation of caffeine and sodiun benzoate in caffeine and sodium benzoate injection by isoabsorption method (isobestic method)," International Journal of Pharmaceutical, Chemical and Biological Sciences, 2011,. 26-31.

[59] Bharate, S. S., Kolhe, S. R. and Bharate, S. B., "Development of validated spectrophotometric method for simultaneous estimation of acetylsalicylic acid and caffeine in pure and tablet dosage form," Journal of Advanced Research, 2011, 34-41.

[60] Guidance for industry: Q2B validation of analytical procedures: Methodology. International Conference of Harmonization (ICH). (https://www.fda.gov/downloads/drugs/guidances/ucm073384.pdf),1996,

[61] CDER center for drug evaluation and research; Reviewer guidance; Validation of chromatographic methods.. (https://www.fda.gov/downloads/drugs/guidances/ucm134409.pdf).,1994

Citation: Mahmoud M. Sebaiy, et.al, "HPLC Method for Simultaneous Determination of Ascorbic acid, Phenylephrine, Paracetamol, Caffeine in Their Pure and Dosage Forms ", International Journal of Advanced Research in Chemical Science, 7(6), pp. 7-16. DOI: https:// doi.org/10.20431/2349-0403.0706002

Copyright: (C) 2020 Authors, This is an open-access article distributed under the terms of the Creative Commons Attribution License, which permits unrestricted use, distribution, and reproduction in any medium, provided the original author and source are credited. 